\title{
PLASMA LEVELS OF ANTI-DIURETIC HORMONE DURING AND AFTER HEART SURGERY WITH EXTRA CORPOREAL CIRCULATION
}

\author{
Magdi G. Soliman, M.B., B.Ch. ANd George F. Brindle, M.D., F.R.C.P.(c)
}

A WATER RETENTION SYNDrome, has been described by Sladen ${ }^{1}$ et al. in 19 per cent of patients, following prolonged mechanical ventilation. They suggested that changes in left atrial pressure, secondary to intermittent positive pressure ventilation (I.P.P.V.) caused an increase in plasma anti-diuretic hormone with resultant water retention.

In studies of plasma anti-diuretic activity of anaesthetized dogs, a significant increase has been reported ${ }^{2}$ following a short period of continuous positive pressure ventilation. However, when intermittent positive pressure ${ }^{3}$ ventilation was employed, there was decrease in A.D.H. plasma level. Studies of A.D.H. response to mechanical ventilation in anaesthetized man by Verma ${ }^{5}$ failed to show any increase in plasma anti-diuretic activity during I.P.P.V. However, Hoshang \& Barat $\mathrm{z}^{4}$ also reported an increase in plasma A.D.H. during I.P.P.V. in concious man.

Since open-heart surgery has its particular features including extra-corporeal circulation, and the use of mechanical ventilation both during and following anaesthesia, this study was designed to investigate changes in A.D.H. plasma levels in cardiac surgery, during which a period of extra-corporeal circulation occurred; I.P.P.V. was employed during and after the operation.

\section{METHODS}

Seven patients undergoing open-heart surgery were studied (Table I). All were free of any significant pulmonary or endocrine disease. Appropriate doses of morphine and atropine or scopolamine were given one hour pre-operatively. Various monitors including electro-cardioscopy, central venous pressure catheters, intra-arterial canulae, rectal thermometers, urinary catheters and intravenous lines were fixed in place.

Following the injection of $3 \mathrm{mgm}$ d-tubocurarine, and five minutes of oxygenation, a sleep dose of thiopentone was given, followed by succinylcholine to facilitate tracheal intubation. Anaesthesia was maintained using nitrous oxide, morphine and d-tubocurarine.

Heparin was given in a dose of $3 \mathrm{mg} / \mathrm{kg}$ of body weight with half of the initial dose repeated at one-hour intervals. The priming solution consisted of $20-25 \mathrm{ml}$ of plasmalyte/ $\mathrm{kg}$ body weight; 44.6 meq sodium bicarbonate and 600 $\mathrm{mg}$ calcium gluconate. The addition of blood to the priming solution was

'Department of Anaesthesia, Faculty of Medicine, University of Sherbrooke, Sherbrooke, Quebec.

Canad. Anaesth. Soc. J., vol. 21, no. 2, March 1974 
TABLE I

\begin{tabular}{llcccc}
\hline & Name & Age & Sex & $\begin{array}{c}\text { ASA } \\
\text { Classification }\end{array}$ & Operation \\
\hline 1 & R.A. & 49 & $\mathrm{~F}$ & 3 & Closure of A.S.D. \\
2 & B.A. & 34 & $\mathrm{~F}$ & 3 & Aortic Valve protheses \\
3 & H.W. & 45 & $\mathrm{M}$ & 3 & Aorto-coronary by-pass \\
4 & T.R. & 64 & $\mathrm{M}$ & 3 & Aorto-coronary by-pass \\
5 & P.G. & 50 & $\mathrm{M}$ & 3 & Aorto-coronary by-pass \\
6 & N.J.-L. & 47 & $\mathrm{M}$ & 3 & Aorto-coronary by-pass \\
7 & A.J. & 66 & $\mathrm{M}$ & 3 & Aorto-coronary by-pass \\
\hline
\end{tabular}

dependant on the patient's pre-operative haematocrit. Protamine sulphate in a dose of $4.5 \mathrm{mg} / \mathrm{kg}$ was given slowly to restore normal blood coagulation; the muscle relaxant was not reversed. Blood loss was measured and replaced.

Seven samples of arterial blood were taken from each patient for measurement of A.D.H. at the following times:

I. Before induction;

II. After induction;

III. During extra-corporeal circulation;

IV. After extra-corporeal circulation (vital signs having been stable for at least $30 \mathrm{~min}$ );

V. Two hours post-operatively;

VI, Immediately before cessation of I.P.P.V.;

VII. Three hours after cessation of I.P.P.V.

The interval between samples exceeded 30 minutes. A.D.H. bioassays were carried out using the technique described by Gilmore ${ }^{9}$ et al. in which the A.D.H. level is determined by the degree of relaxation of rabbit rectal muscle. Arterial blood gases, serum osmolality and electrolytes and urine osmolalities were determined. Urine volumes were recorded, and vital signs including arterial and central venous pressures and electro-cardioscopy were monitored during the period of study. All patients received I.P.P.V. for at least 20 hours using the Bennett MA-1 ventilator. Severance from the ventilator was then accomplished in one step. Morphine was given during the post-operative period to relieve pain and facilitate mechanical ventilation.

\section{Rfsults}

The changes in A.D.H. plasma levels at the times of sampling during the period of study are shown in Figure 1. There was a significant increase in the plasma levels of A.D.H. during surgery, with the highest level reached during the period following extra-corporeal circulation. The levels then gradually decreased during the post-operative period of the study.

In five patients the A.D.H. plasma levels returned to values not significantly different from the pre-operative period. In the other two patients the levels of A.D.H. during the post-operative period remained at values significantly higher than their pre-operative levels and, in addition, they were significantly higher than the post-operative levels of the other patients. 


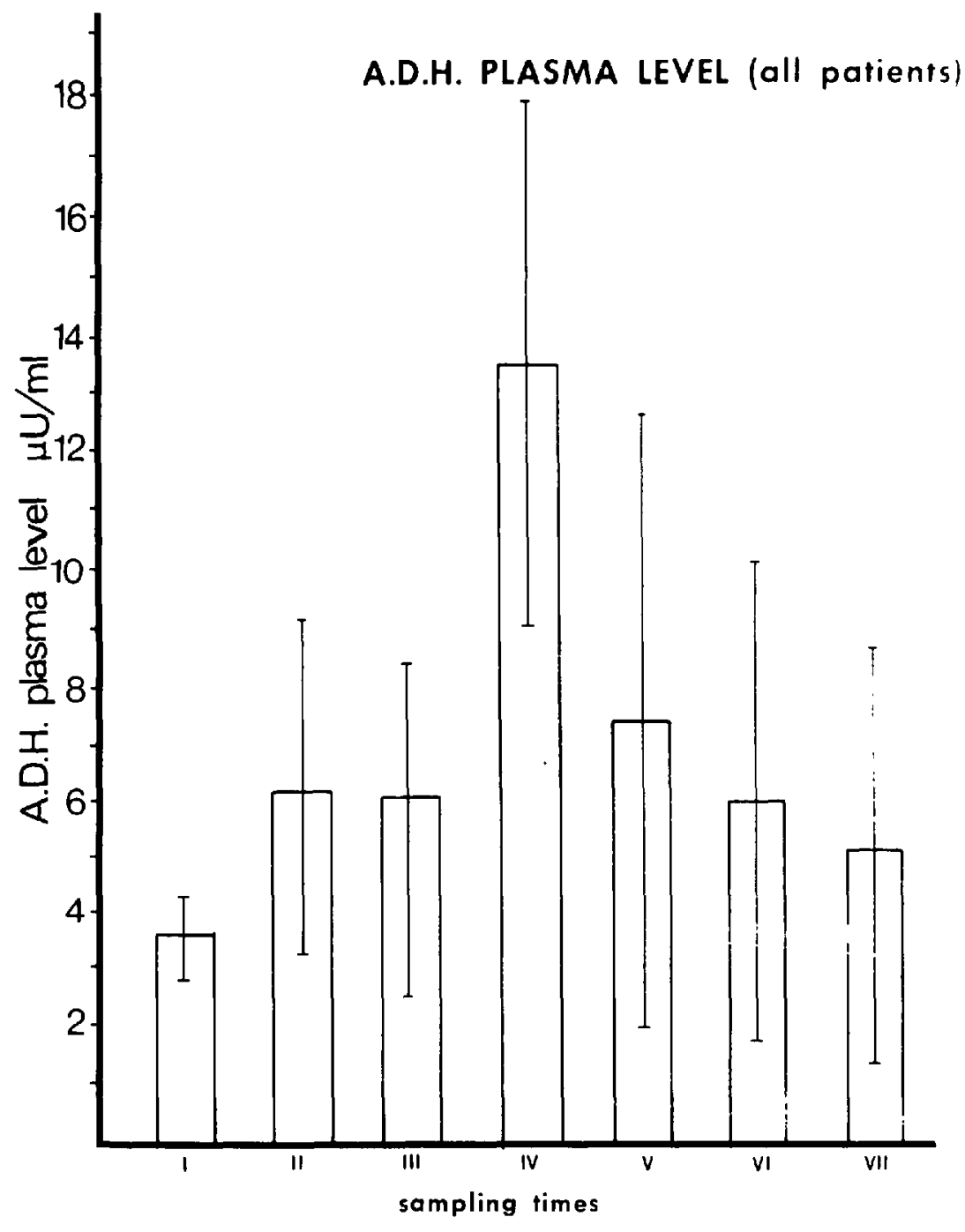

Figure 1,

On the basis of this difference, the patients were divided into two groups: Group I Those in which the A.D.H. returned to within pre-operative values. Grour II Those in whom the A.D.H. remained above pre-operative values.

Figure 2 compares the mean levels and standard deviation of A.D.H. of the two groups.

Changes in serum osmolality at the times of A.D.H. sampling, shown in Figure 3, were proportional to changes in A.D.H. plasma levels, the highest value occurring during extra-corporeal perfusion. The changes in serum osmolality in the two groups are compared in Figure 4. There was no significant difference between them.

Table II shows the fluids given to replace insensible fluid loss; there was no significant difference between the two groups. 


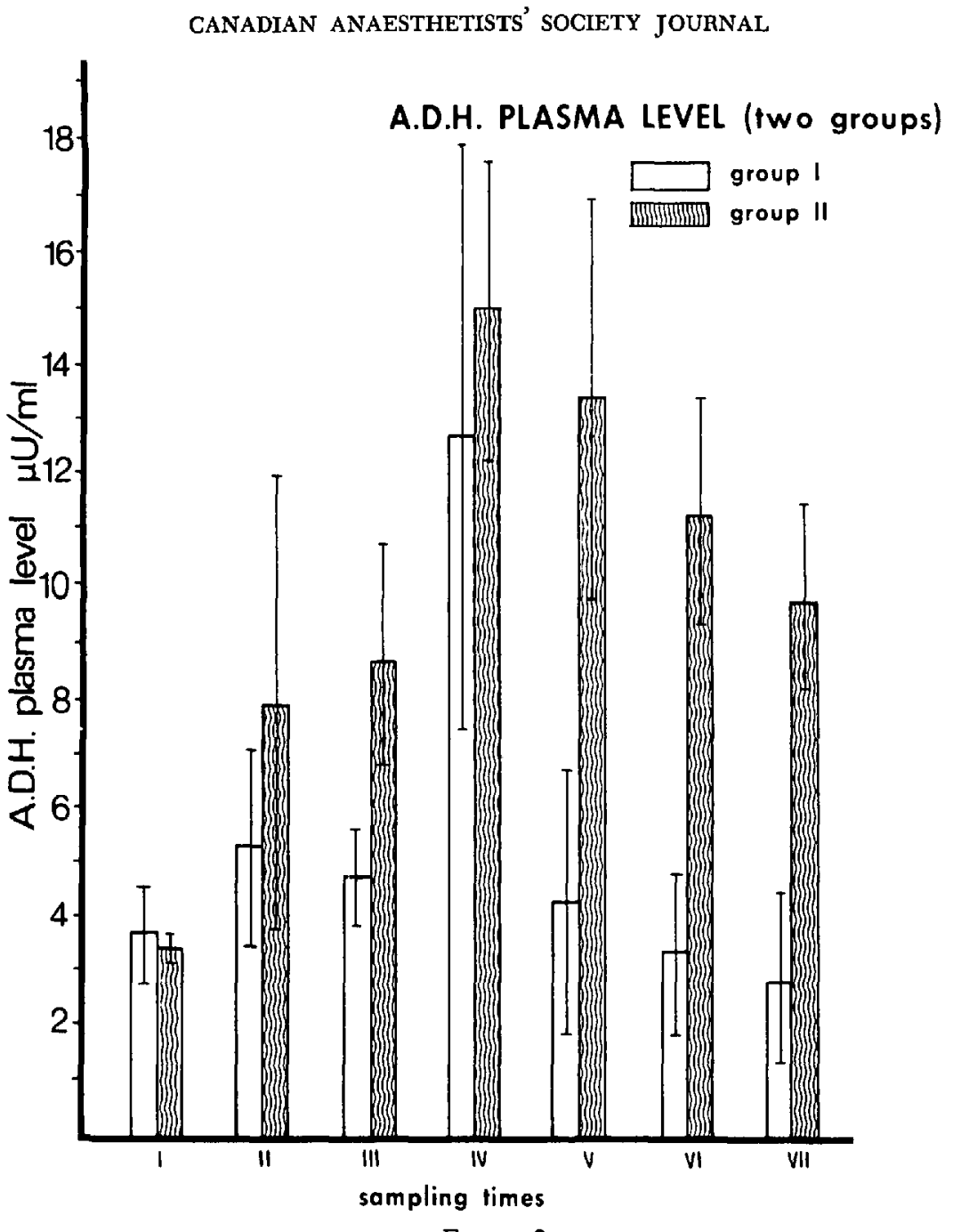

Figure 2.

TABLE II

FLUIDS INTAKE TO REPLACE Non-Sensible Fluids Loss

\begin{tabular}{lcc}
\hline & Mean & \\
& in $\mathrm{L} / \mathrm{m}^{2} / 24 \mathrm{H}$ & ST.D. \\
\hline All patients & 1.016 & \pm 0.277 \\
Group I & 1.02 & \pm 0.318 \\
Group II & 1.005 & \pm 0.125 \\
\hline
\end{tabular}

The doses of morphine given during the study are shown in Table III. A significant difference was observed between doses of morphine received by the two groups of patients.

Table IV shows the blood gases and acid base status at the times of A.D.H. sampling. There was no gross deviation from normal values. Sodium plasma 


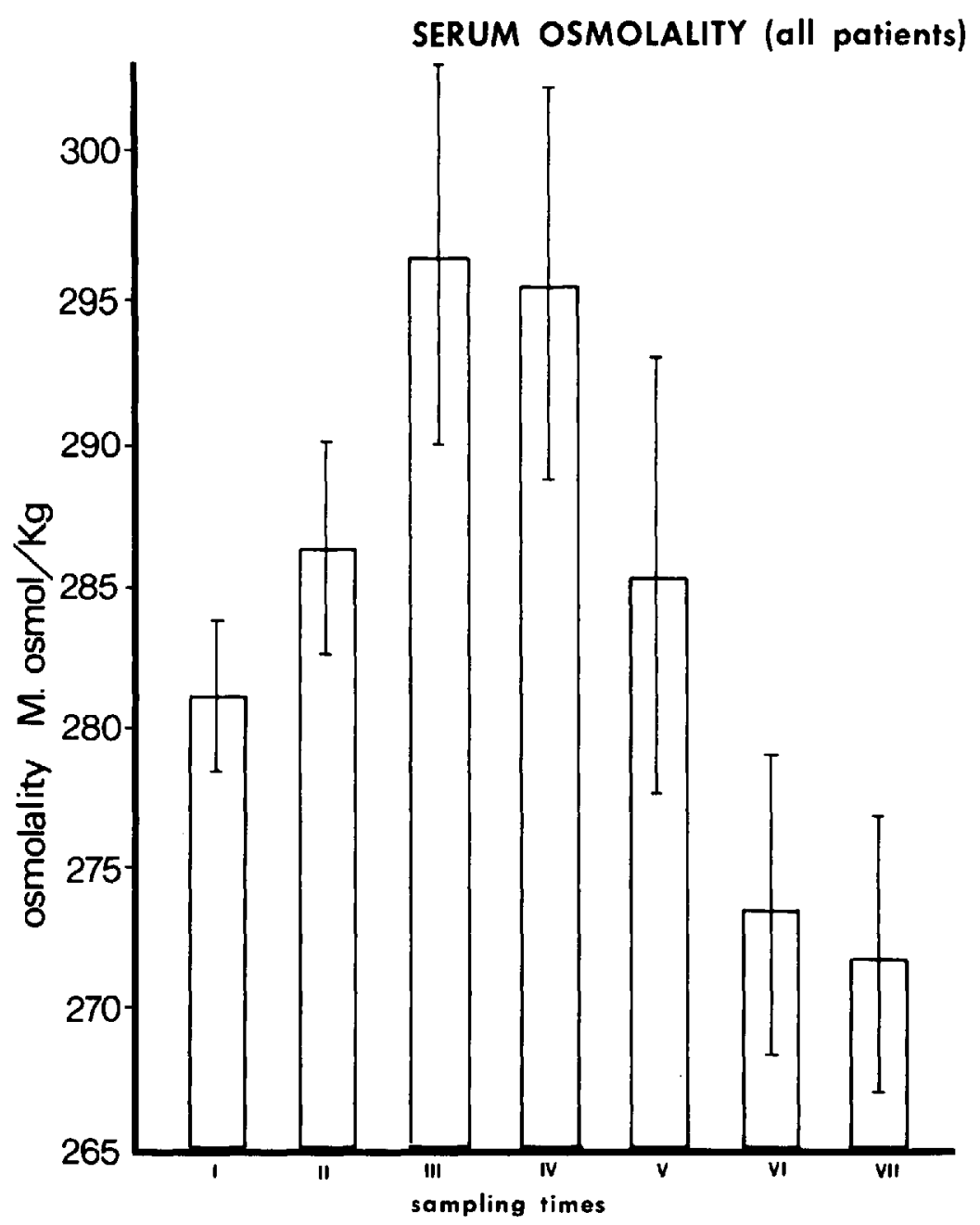

Figure 3.

levels during the study are shown in Figure 5. There was slight hyponatraemia during the extra-corporeal perfusion. Vital signs were maintained within preoperative values during operation and in the post-operative period.

\section{Discussion}

Several factors may change the A.D.H. plasma levels during and after surgery. The most important of these are serum osmolality, ${ }^{12}$ hypotension, blood loss, ${ }^{12}$ painful stimuli and surgical trauma, ${ }^{14,19}$ changes in left atrial pressure, ${ }^{22-24}$ vagal stimulation, ${ }^{12}$ anaesthetic and other drugs, ${ }^{6,7,8,15,16,17}$ and psychogenic factors. ${ }^{20,21}$

The pre-induction levels of A.D.H. may be slightly higher than the normal steady state levels, due mainly to a degree of dehydration and the use of drugs for premedication. Pre-operative anxiety may also have an effect. The increase in the A.D.H. plasma levels during the operation could be related to surgical trauma, anaesthetic drugs, and changes in serum osmolality. 


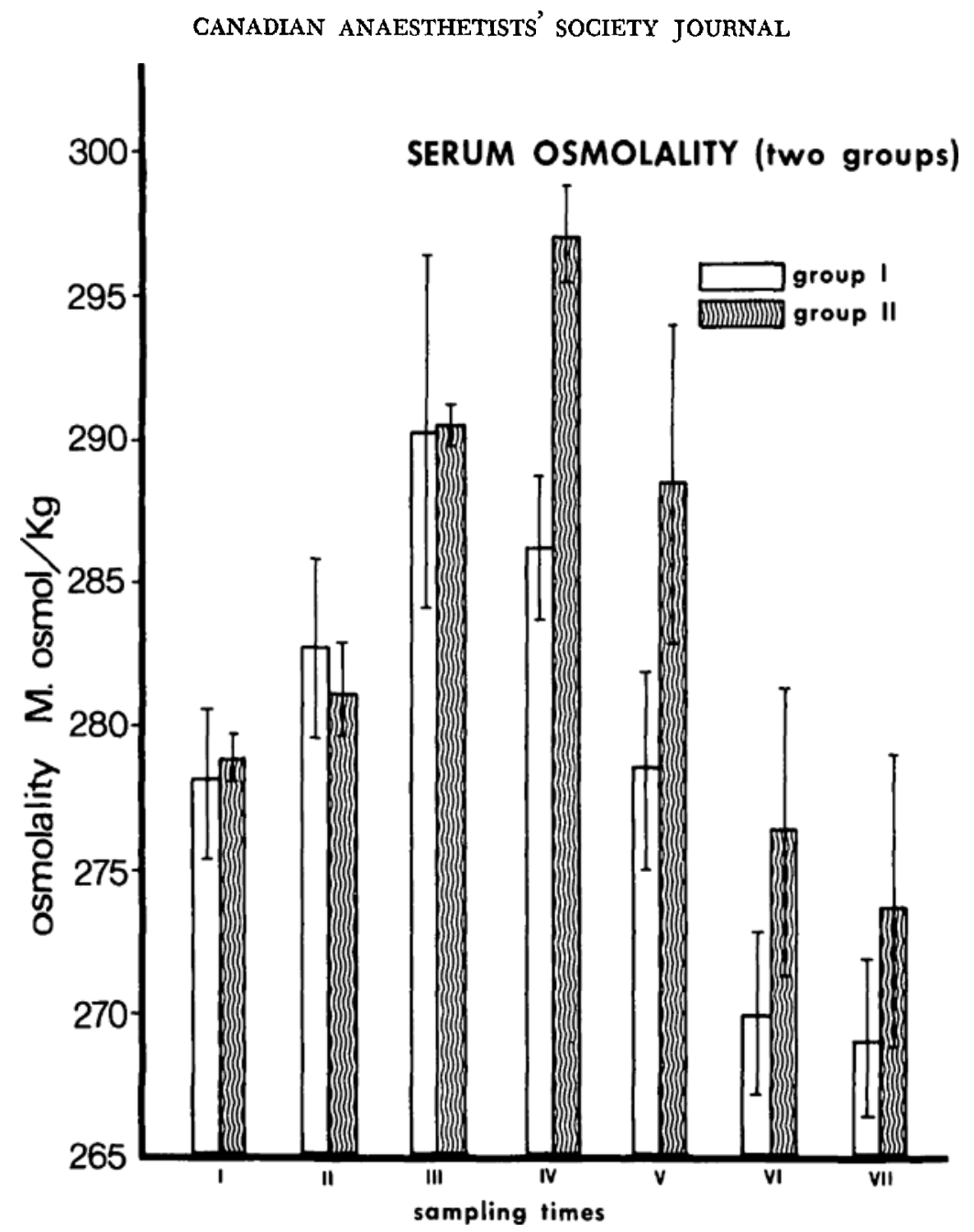

Figure 4.

TABLE III

Morphine Given During the Period OF StUdY

\begin{tabular}{lll}
\hline \hline & $\begin{array}{c}\text { Mean } \\
\mathrm{mg} / \mathrm{kg}\end{array}$ & ST.D. \\
\hline All patients & 0.911 & \pm 0.222 \\
Group I & $0.822^{*}$ & \pm 0.2 \\
Group II & $1.135^{*}$ & \pm 0.052 \\
\hline${ }^{*} \mathrm{p}<0.025$. & &
\end{tabular}

During the extra-corporeal perfusion changes occurred in the characteristics of the blood pressure wave, there was a slight decrease in the mean arterial blood pressure, and a considerable increase in serum osmolality was recorded. Since these changes are usually associated with an increase in plasma levels of A.D.H., we anticipated a further increase in the plasma level above that noted im- 


\section{$\mathrm{Na}^{+}$LEVEL}

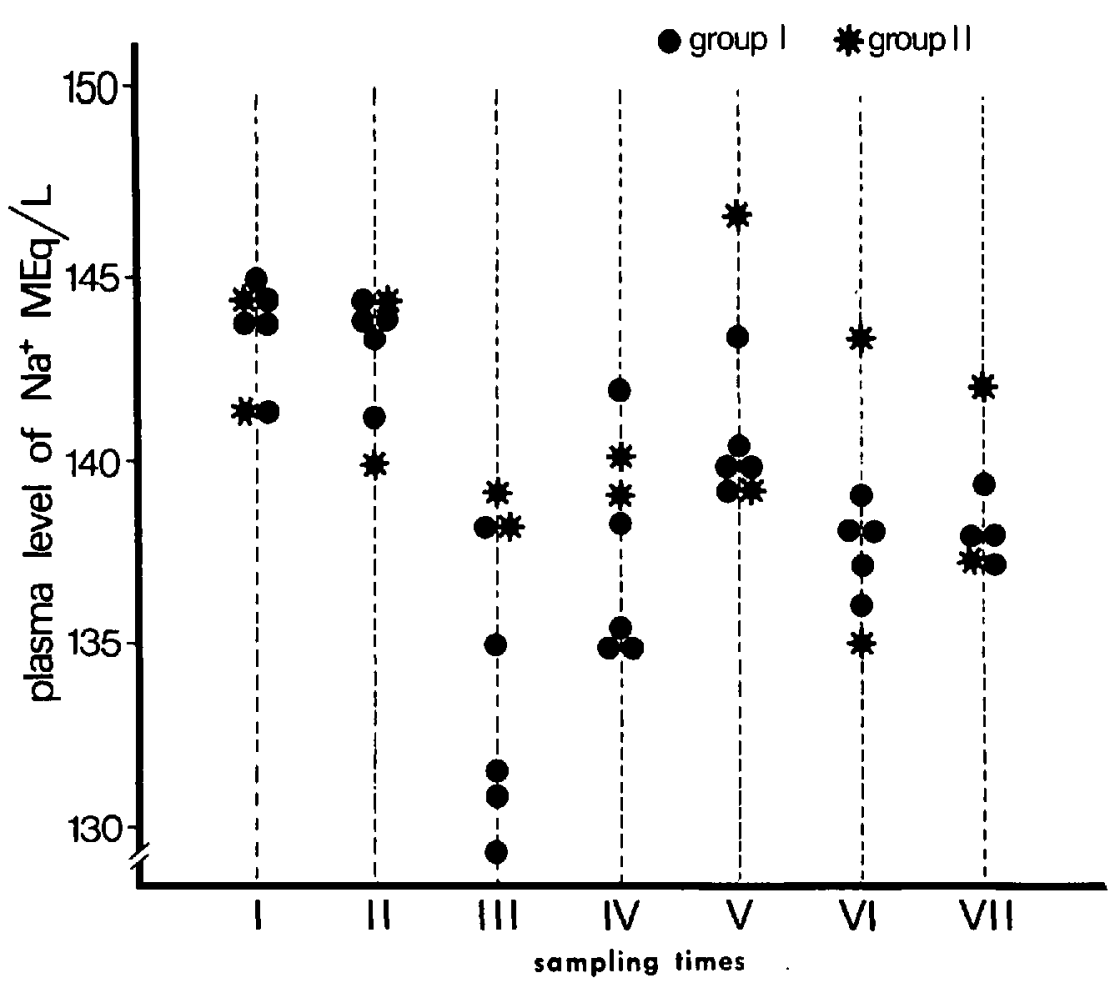

Figure 5.

TABLE IV

Arterial Blood Gases and Acid Base Status at the Times of A.D.H. Sampling

\begin{tabular}{crrrr}
\hline \hline Sampling Time & \multicolumn{1}{c}{$\mathrm{PO}_{2}$} & \multicolumn{1}{c}{$\mathrm{PCO}_{2}$} & $\mathrm{pH}$ & \multicolumn{1}{c}{$\mathrm{HCO}_{3}$} \\
\hline I before induction & $67 \pm 9$ & $37 \pm 2$ & $7.38 \pm 0.02$ & $22 \pm 1.8$ \\
Il after induction & $141 \pm 21$ & $34 \pm 5$ & $7.42 \pm 0.06$ & $22 \pm 1.7$ \\
III during E.C.C. & $240 \pm 108$ & $39 \pm 4$ & $7.34 \pm 0.04$ & $19.5 \pm 1.2$ \\
IV after E.C.C. & $159 \pm 29$ & $38 \pm 6$ & $7.37 \pm 0.04$ & $21 \pm 1.3$ \\
V 2 hours post op. & $170 \pm 45$ & $39 \pm 6$ & $7.41 \pm 0.05$ & $24.5 \pm 2.8$ \\
VI End of 1.P.P.V. & $127 \pm 37$ & $37 \pm 6$ & $7.41 \pm 0.03$ & $21.4 \pm 3.8$ \\
VII 3 hours spont. resp. & $130 \pm 34$ & $37 \pm 2$ & $7.44 \pm 0.01$ & $24 \pm 1.9$ \\
\hline
\end{tabular}

mediately prior to the onset of extra-corporeal perfusion. In fact, a slight decrease was observed and one can only speculate as to the importance of the haemodilution which occurred during the period of extra-corporeal circulation to explain this decrease; an increase in the rate of A.D.H. metabolism may play a role.

The decrease in plasma levels of A.D.H. during the post-operative period was anticipated, since most of the factors responsible for the high levels during operation were no longer present. The exact cause of the persistence of high A.D.H. plasma level in two patients is unknown. 
Several studies have demonstrated that morphine has an anti-diuretic action in man. ${ }^{15-18}$ This has been attributed to either an increase in A.D.H. activity or to a direct effect of morphine on renal haemodynamics. In this study there was a significant difference in the doses of morphine $/ \mathrm{kg}$ in the two groups of patients. It is possible that the higher doses of morphine were responsible for the persistence of high plasma levels of A.D.H. in two of the patients. However, further studies are required to clarify the nature of the anti-diuretic effects of morphine.

Dehydration is one of the strongest stimuli for A.D.H. secretion; however, the absence of a significant difference in serum osmolality and fluid intake between the two groups of patients would seem to rule out dehydration as a cause.

Several studies have demonstrated a relation between plasma levels of A.D.H. and changes in left atrial pressure. ${ }^{22.23 .24}$ The possibility of a difference in the left atrial pressures between the two groups can not be definitely ruled out, since direct measurements were not made. The absence of any significant difference in the ventilatory treatment of these patients and the persistence of high levels of A.D.H. following three hours of spontaneous respiration would seem to minimize the importance of the respirator as a cause of changes in left atrial pressure which might result in an increase in plasma A.D.H.

Response to pain and psychogenic factors are other two possibilities to explain the persistence of high A.D.H. plasma levels in the two patients. We observed that the differences in A.D.H. plasma levels between the two groups appeared early during the post-operative period, when most of the patients were still under heavy sedation and were free of pain. This would tend to reduce the importance of these factors as a cause. However, it is still possible that the increase in the A.D.H. level was triggered by other factors and persisted duc to psychogenic factors and pain.

\section{SUMMARY}

Plasma levels of antidiuretic hormone (ADH) increased in seven patients during cardiac surgery using extra-corporeal circulation, probably due to changes in serum osmolalities, surgical trauma and the action of anaesthetic drugs.

The levels of A.D.H. returned to pre-operative levels within a few hours following in all but two of the seven patients. The treatment of these two patients differed only in that they received higher doses of morphine than the other subjects.

The level of A.D.H. remained high following three hours of spontaneous respiration and this would seem to discount the importance of I.P.P.V. as a stimulus to A.D.H. secretion.

\section{RÉSUMÉ}

Ce travail rapporte les variations plasmatiques en hormone anti-diurétique observées chez sept patients, durant et après chirurgie à cœur ouvert. Après une induction au Thiopenthal, ces patients furent maintenus anesthésiés avec de la Morphine et un mélange de Protoxyde et d'Oxygène. Les taux d'A.D.H. furent déterminés en étudiant le degré de relâchement rectal du lapin. ${ }^{9}$

Une élévation significative des niveaux plasmatiques d'Hormone Anti-diuréti- 
que fut observée dans tous les cas. Ces chiffres revinrent à la normale quelques heures après l'opération chez tous les malades sauf deux. Ces deux malades avaient reçu des doses de Morphine plus élevées que les autres. Il est possible que les doses élevées de Morphine aient été la cause de ce phénomène.

Ces deux patients avaient des paramètres ventilatoires semblables aux autres et le fait que leurs taux d'Hormone anti-diurétique demeurent élevés trois heures après retour à la respiration spontannée, nous semble éliminer la Pression Positive Intermittente comme cause principale.

\section{ACKNOWLEDGMENTS}

The authors acknowledge with gratitude the invaluable co-operation of Doctor Denys Gagnon, Ph.D., Associate Professor, Department of Pharmacology, Sherbrooke University, and members of his department for measuring the A.D.H. plasma levels.

\section{REFERENCES}

1. Sladen, A., Laver, M.B., \& Pontoppidan, H. Pulmonary complications and water retention in prolonged mechanical ventilation. New Eng. J. Med, 279: No, 9. 448-453 (1968).

2. Baratz, R.A. \& Ingraham, R.C. Renal hemodynamics and antidiuretic hormone release associated with volume regulation. Amer. J. Physiol. 198: 565 (1960).

3. Baratz, R.A., Philbin, D.M., \& Patrerson, R.W. Urinary output and plasma levels of antidiuretic hormone during intermittent positive-pressure breathing in the dog. Anesthesiology 32: No. 1, 17-22 (1970).

4. Hoshang, J. Khambatta \& Baratz, Robert A. I.P.P.V., plasma A.D.H. and urine flow in conscious man. J. Appl. Physiol. 33: No. 3, 362-364 (1972).

5. Verma, A.Y., Gupta, K.K., McHra, S., \& Chaudhury, R.R. Intermittent positive pressure respiration in human subjects. Ind. J. Med. Res. 56: No. 1, 73-77 (1968).

6. Oyama, T., Sato, K., \& Kimura, K. Plasma levels of antidiuretic hormone in man during halothane anaesthesia and surgery. Canad. Anaesth. Soc. J. 18: No. 6, 614 (1971).

7. Oyama, T. \& Sato, K. Plasma levels of antidiuretic hormone in man during methoxyflurane anaesthesia and surgery. Anaesthesia 25: No. 4, 500 (1970).

8. Oyama, T. \& Kimuna, K. Plasma levels of antidiuretic hormone in man during diethylether anaesthesia and surgery. Canad. Anaesth. Soc. J. 17: No. 5, 495 (1970).

9. Gilmone, N.J. \& VANE, J.R. A sensitive and specific assay for vasopressin in the circulating blood. Br. J. Pharmac. 38; 633-652 (1970).

10. Bisset, G.W., Hrzton, S.M., \& Poisner Hypothalamic pathways for independent release of vasopressin. Proc. Roy. Soc. 166: 422 (1967).

11. ARNEIL, G.C. \& WiLson, H.E.C. Isolation of pituitry antidiuretic peptide and similar urinary peptides by paper chromatography. Lancet, p. 568 (1953).

12. Share, Leonaro Vasopressin, its bio-assay and the physiological control of its release. Am. J. Med. 42: 701 (1967).

13. Bonjoun, Jean-Philippe \& Malvin, R.L. Plasma concentration of A.D.H. in conscious and anesthetized dogs. Am. J. Physiol. 218: No. 4. 1128 (1970).

14. Moran, Walter H. \& ZimmermanN, B. Mechanisms of antidiuretic hormone control of importance to the surgical patient. Surgery 62: No. 4, 639-644 (1967).

15. BECKMAN, L. The antidiuretic effects of anaesthetic agents. Anesthesiology 16: 939 (1955).

16. Debono, R.C. Antidiuretic action of morphine and its mechanism. J. Pharmacol. Exp. Therap. 82: 74 ( 1944 ).

17. Duke, H.N. The antidiuretic action of morphine sulphate and mode of action in the hypothalamus of the dog. Quart. J. Exper. Physiol. 36: 149 (1951).

18. Paper, S., Saxon, L., Burg, M.B., Seifer, H.W., \& Rosenbaum, J.D. The effect of morphine sulfate upon the renal excretion of water and solute in man. J. Lab. Clinic Med. 50: 692 (1957). 
19. UkaI, M., Moran, W.H., \& ZimmermanN, B. The role of visceral afferent pathways on vasopressin secretion and urinary excretory pattern during surgical stress. Ann. Sur. 168: 16-28 (1968).

20. NASH, F.D. Contol of antidiuretic hormone secretion: introduction remark. Fed. Proceeding 30: 1376-1377 (1971).

21. Rydin, H. \& Verney, E.B. Inhibition of water diuresis by emotional stress and by muscular exercise. Quart. J. Exptl. Physiol. 27: 343-374 (1938).

22. Johnson, J.A.. Moore, W.W., \& Segar, W.E. Small changes in left atrial pressure and plasma antidiuretic hormone titers in dogs. Am. J. Physiol. 217: No. 1, 210 (1969).

23. Baisset, A. \& Montastruc, P. Polyurie par distension auriculaire chez le chien; rôle de l'hormone antidiurétique. J. Physiol. Paris, 49: 91-102 (1959).

24. Lydtis, H. \& Hamilton, W.F. Effect of acute changes in left atrial pressure on urine flow in unanaesthetized dogs. Am. J. Physiol. 207: 530-536 (1964).

25. Lauson, H.D. Metabolism of antidiuretic hormones. Am. J. Med. 42: 713-744 (1967). 